\title{
QualityMatters: How and under what conditions does quality in early education and care matter? A study across four European countries ${ }^{1}$
}

\begin{abstract}
QualityMatters, an extension of a European Commission funded study, the CARE project, intends to examine whether the quality of teacher-child interactions varies as a function of particular classroom features (e.g., types of activities, content, and grouping), to answer the overarching question: how and under what conditions does quality in early education and care matter? Through a cross-cultural process-oriented approach, the researchers in QualityMatters will capitalize on the variation in the ECEC systems present in 4 European countries (Finland, Netherlands, Poland, Portugal) to examine the complex relations of teachers' choices regarding the activity and teacher-child interactions. The project will examine the extent to which children's classroom interactions with teachers vary across activity settings, while taking into consideration country specifications regarding structural regulations. While much of the ECEC research has examined process and structural quality as separated constructs, QualityMatters will look at aspects at the intersection of process and structure, likely to be relevant for child development and learning.
\end{abstract}

Keywords: ECEC quality, teacher-child interactions, cross-country.

\footnotetext{
* University of Porto, Portugal.

${ }^{1}$ Uczestnicy projektu: Clara Barata, University of Coimbra, Portugal; Olga Wyslowska, University of Warsaw, Poland; Carolina Guedes, University of Porto, Portugal; Teresa Aguiar, University of Porto, Portugal; Pauline Slot, University of Utrecht, Netherlands; Jenni Salminen, University of Jyvaskyla, Finland; Cecília Aguiar, ISCTE-IUL, Portugal; Marja-Kristiina Lerkkanen, University of Jyvaskyla, Finland.
} 


\title{
QualityMatters: W jaki sposób i w jakich warunkach istotna jest jakość we wczesnej edukacji i opiece? Badanie w czterech krajach europejskich
}

\begin{abstract}
Abstrakt
QualityMatters to kontynuacja projektu CARE finansowanego przez Komisję Europejską. Celem projektu jest zbadanie, czy jakość interakcji między nauczycielem i dzieckiem jest różna w zależności od poszczególnych cech charakteryzujących klasę (np. rodzaje aktywności, treści i grup), aby znaleźć odpowiedź na nadrzędne pytanie: w jaki sposób i w jakich warunkach jakość w zakresie wczesnej edukacji i opieki ma znaczenie? Dzięki międzykulturowemu podejściu zorientowanemu na proces naukowcy zaangażowani w QualityMatters wykorzystają różnorodność systemów ECEC obecnych w 4 krajach europejskich (Finlandia, Holandia, Polska, Portugalia) w celu zbadania złożonych relacji, związanych z wyborami dokonywanymi przez nauczycieli $\mathrm{w}$ zakresie działalności i interakcji między nauczycielem a dzieckiem. W naszym projekcie przeanalizujemy zakres, w jakim interakcje dzieci w klasie z nauczycielami różnią się w zależności od warunków aktywności, biorąc pod uwagę specyfikacje krajowe dotyczące przepisów strukturalnych. Podczas gdy znaczna część badań dotyczących ECEC traktowała jakość strukturalną i procesową jako oddzielne konstrukty, QualityMatters przeanalizuje aspekty w miejscu krzyżowania się procesów i struktur, które prawdopodobnie okażą się istotne dla rozwoju dziecka i uczenia się.
\end{abstract}

Słowa kluczowe:: jakość systemu ECEC, interakcje nauczyciel-dziecko, przegląd międzynarodowy.

\section{Introduction}

It is widely recognized that young children develop key competences for later school and social success through interactions with adults, peers and learning activities in the early childhood education and care (ECEC) settings. Current evidence clearly indicates that the quality of early childhood education and care (ECEC) is a critical feature associated with better social and cognitive outcomes (Cadima, Leal, Burchinal 2010; Lerkkanen et al. 2012; Mashburn, Pianta, Hamre, Downer, Barbarin, Bryant, Burchinal, Early, Howes 2008).

The concept of quality, however, is not univocal and there are a variety of perspectives conceptualizing and measuring ECEC quality (Melhuish 2004). Theoretical definitions commonly distinguish two broad features: process and structural quality. Process quality refers to children's daily experiences in the classroom, including stimulating interactions and overall warm climate (Cryer, Tietze, Burchinal, Leal, Palacios 1999; Howes, Wishard, Fuligni, Zucker, Lee, Obregon, Spivak 2011). Among process quality features, teacher-child interactions have received 
increasing attention in research as an important pathway to child development (Hamre et al. 2013). Several studies, including from our research team, indicate that high-quality teacher-child interactions are associated with improvements in both academic and social skills (Cadima et al. 2010; Lerkkanen et al. 2012; Mashburn et al. 2008).

Structural quality refers to aspects that are relatively stable day to day, including staff qualifications, group size, and available materials. Structural quality is usually under national regulations and is viewed as providing the conditions for process quality (Cryer et al. 1999). Currently, in Europe, the central issue is not whether to invest in ECEC quality, but rather how much and in which dimensions to do so (Leseman 2013). Investments have usually focused on structural aspects, such as decreasing ratios, because these aspects of quality are easier to regulate. However, the strength of association from structural quality to process quality; and from process quality to child development is still unclear. Moreover, these associations may differ between types of ECEC provision (e.g.,crèches vs preschools) and European countries (Leseman 2013).

Studies on the associations between dimensions of ECEC quality show mixed findings, with some studies showing associations between particular structural quality characteristics (e.g., small group sizes) and higher process quality, and other studies reporting no such effects (Mashburn et al. 2008; Cryer et al. 1999; Barros, Aguiar 2010; Pessanha, Aguiar, Bairrão 2007). Similarly, although several studies have found positive effects of process quality on child outcomes (Cadima et al. 2016; Mashburn et al. 2008), the effects have been somewhat small and inconsistent across studies. The inconclusive evidence suggests complex interactions among ECEC quality and child outcomes. It is possible that particular classroom quality features moderate the effect of one another (e.g., higher group sizes may be compensated by efficient classroom management; Leseman 2013). In fact, recent research on ECEC quality has emphasized the need to look at varying quality effects, rather than expecting the same quality features to produce the same effects on child outcomes (Phillips, Fox, Gunnar 2011). Moreover, prior studies of ECEC quality have overlooked how country-level regulations, policy and cultural traditions may have restricted the variation to be explained. Particularly for children under 3, the ECEC arrangements vary greatly from country to country.

\section{Country-level regulations and policy issues in Poland, Portugal, Netherlands and Finland}

This study is focused in four countries that have common, but also distinctive characteristics regarding ECEC regulations and participation rates.

Regarding the organization of the ECEC system, in the Netherlands, Poland and Portugal, ECEC services are structured according to the age of the children and 
provision is split into two separate phases, with the responsibility for ECEC regulation divided between different ministries (European Commission/EACEA/ Eurydice/Eurostat 2014). These countries do not have steering documents to guide educational practices, and guidelines to foster cognitive or language development are less apparent. In contrast, in Finland ECEC provision is organized in a single phase covering the whole age range, under the guardianship of the ministry of education.

Regulations in Portugal specify both the maximum number of children per staff member and per group (1:7 and 1:9, and 14 and 18, respectively for 1-year-old and 2-years-olds), in the Netherlands the staff/child ratios are 1:5 for 1-year-olds and 1:6 for 2-years-olds and 16 is the maximum number of children per group; while in Finland and in Poland, only staff/child ratios are defined: in Finland a staff/child ratio of $1: 3$ and in Poland a staff/ratio of 5 in terms of children up to 12 months, and 8 for children older than a year (European Commission/EACEA/Eurydice/ Eurostat 2014).

The type of professionals involved in ECEC settings also vary within these four countries. In Portuguese settings we find two main types of professionals: educational staff (educators) responsible for designing and implementing educational programs, who are required to have a master's level; and assistants/auxiliary staff working in collaboration and supporting educators, with upper secondary level as the minimum educational level required. In Finland we encounter both educational staff who have a bachelor's level (at minimum) and care staff (who team up with the educational staff) with an upper secondary level. Similarly, in the Netherlands we find the same two types of professionals as in Finland, the only difference being the level of education required for educational staff which is post-secondary nontertiary education. In Poland's settings we only find care staff (working independently in childcare and developing and putting in action learning activities) with the same minimum level of education as the care staff in Finland and the Netherlands (European Commission/EACEA/Eurydice/Eurostat 2014; Resa, ErekyStevens, Wieduwilt, Penderi, Anders, Petrogiannis, Melhuish 2016).

The countries are also different in terms of participation rates and the average of weekly hours of provision. The attendance rate for children under 3 in the Netherlands is very high, $46 \%$, and most young children attend ECEC part-time. The weekly hours average in centre-based ECEC is relatively low, 18 hours, which contrasts with Portugal and Poland, where ECEC settings generally provide extensive opening hours (nearly 39 hours per week). Portugal has also one the highest full-time attendance rates, 34\%, while in Poland the attendance rate is quite low, $3 \%$. In Finland, the attendance rate is nearly $25 \%$, and there are both services covering the working day (20\% of attendance) and providing care for only few hours a week $(6 \%)$. 


\section{How teachers organize the day?}

Recent research has highlighted that other classroom features that are not either structural or process features may also be important to consider. One important factor that might help understand the variation on the effects of classroom quality is the type of activity setting (e.g., large group, free choice, routines). Teachers use different activity settings to structure children's time throughout the day and the structure of the settings is likely to play a role in the type of opportunities created for interaction.

The amount of time that children are expected to engage in activity settings, such as small group, routines, or free play, can play a major role in the ways children interact with the teacher, relate to each other, and learn (Booren, Downer, Vitiello 2013; Cabell, DeCoster, LoCasale-Crouch, Hamre, Pianta 2013; Early et al. 2010; Fuligni et al. 2012; Howes et al. 2011).

One recent study from the USA indicated that the quality of preschooler's interactions varied as a function of activity setting. Specifically, the quality of teacherchild interactions was higher in teacher-structured settings, while children's interactions with peers were more positive in free choice settings (Booren et al. 2013). In another study, the authors found that the effectiveness of teachers' instructional interactions was higher in the large group setting, compared to free choice and routine settings. Findings also suggested that science activities, either in large group or free choice, represented the most effective global instructional interactions settings (Cabell et al. 2013). In a study involving public center-based preschool programs in the United States, Fuligni et al. (2012) identified two profiles to describe the daily routines of children: A high free pattern, in which children spent most of their day engaged in child-directed activities, and structuredbalanced patter, in which children spent their day engaged both in child-directed free-choice activities and teacher-directed activities. Even though the profiles were not related to process quality, they were associated with children's language scores and opportunities to engage in language and literacy and math activities, calling attention for the importance of ways teachers structure the day in the provision of learning experiences.

Understanding whether teachers provide similar levels of interactions quality throughout the day or whether they elect specific moments to provide high-quality interactions remains an important research question. This can help teachers identify the most powerful learning opportunities across the day.

However, no study yet has examined this issue in classrooms serving younger children or in Europe, where greater variation in classroom features is expected (OECD 2006). While much of the research on ECEC has been on preschoolers, little empirical work has investigated classroom quality for toddlers, especially in Europe. Toddlerhood is a unique developmental period of rapid growth (La Paro, Williamson, Hatfield 2014). Neuroscience research has revealed the existence of sensitive periods in which the developing brain is susceptible to environmental 
influences (Shonkoff, Phillips 2000). For toddlers, an important part of the day is spent in routines and it is widely believed that responsive interactions during these settings are very important for learning (La Paro et al. 2014). Understanding how much teachers provide similar levels across the day or elect specific moments for high-quality interactions remains an important research question.

\section{Curriculum Quality Analysis and Impact Review of European Early Childhood Education and Care (CARE) project}

In one recent European project (the Curriculum Quality Analysis and Impact Review of European Early Childhood Education and Care [CARE], funded by the European Union's 7th Framework program THEME [SSH.2013.3.2-2] Early childhood education and care: promoting quality for individual, social and economic), the CARE project (2014-2017), a multiple case study was conducted in seven European countries to examine common and culturally differing aspects of curriculum, pedagogy, and quality of ECEC provisions (Slot, Cadima, Salminen, Pastori, Lerkkanen 2016). This multiple case study involved intensive data collection on the quality of teacher-child interactions and structural features in a total of 28 ECEC centers, that were considered examples of 'good practice'. Videos were made of four common activity settings in ECEC (specifically, play, educational/emerging academic activities, mealtime, and creative activities).

Findings showed that the overall emotional tone of the classrooms was very positive and that teachers in general were close, warm and sensitive to young children's individual needs. But there was also considerable variation in the quality of teacher-child interactions that could be attributed to the age group (0-3-yearsolds vs. 3-6 years-olds), type of activity (play vs. educational), group size (small vs. large group) and to constellations of structural characteristics of the participating centres (Slot et al. 2016). Although findings from this multiple case study should be taken as exploratory, they are nevertheless very important by suggesting that choices educators make in preparing and organizing the day may have an impact on the quality of teacher-child interactions.

\section{Quality Matters}

QualityMatters (2016-2019), an extension of the CARE project, intends to examine the extent to which children's classroom interactions with teachers vary across activity settings. Specifically, two research questions are addressed:

1. How can toddler classroom experiences be characterized in terms of activity settings and quality of teacher-child interactions in the four European countries? 
2. To what extent do activity settings determine the quality of teacher-child interactions, after accounting for potential differences in structural quality across the four European countries?

This study will use a sample of 30 toddler classrooms per country in a total of 120. Classrooms have been carefully recruited through a set of selection criteria that includes sociocultural diversity while ensuring that the classroom structural characteristics are aligned with national regulations and thus representative of the country. The study will follow a cross-sectional cross-cultural design, in which videos of the classroom experiences will be video recorded and analyzed in several layers and by independent researchers. A strong collaboration among researchers from different countries will support cross-country comparability. Pilot visits to each country already contributed to specify recommendations for video observations. Specifically, four commonly provided activities that reflect children's regular experiences in the classroom will be videotaped (Play, Literacy, mathematics or science activities, meals, and creative activities, e.g. craft, music, movement and/or dance). The activity setting will be coded through a range of indicators based on the literature, namely (a) group size, (b) teacher role (active vs passive involvement) (c) activity type (e.g., routine, free choice) (d) and content (e.g., literacy). The quality of teacher-child interactions will be scored using the CLASS-Toddler (La Paro, Hamre, Pianta 2012) by certified observers from the different countries. The CLASS-Toddler focuses on aspects of emotional and behavioral support and engaged support for learning and its validity and reliability has been established in the participating countries. CLASS will be scored from the videotapes. For interrater reliability, videos from each country will be rated by observers from different countries. In addition to the observation scales, we will use a teacher-report measure to collect data on important structural characteristics (e.g., group size, space and materials, teacher/assistants characteristics).

The study will provide information regarding whether particular activity settings are more amenable than others to high-quality interactions that can be intentionally used by the teacher. To our knowledge, this is among the first studies examining such effects. This study will also focus on the quality of care available to toddlers in Europe and locally, an important period that has received less attention from the field. Finally, the cross-cultural approach and strong collaboration among researchers will enhance the relevance of the study results at both European and national level.

While much of the empirical research has examined main effects of ECEC quality, in QualityMatters we will examine the variations of both levels and effects of teacher-child interactions across the day, contributing to determine under what conditions does ECEC quality influence child development and learning. We will look at varying effects of activity settings and teacher-child interactions. Given that these important aspects can be structured intentionally by the teacher, our findings 
will contribute to identify the most powerful learning opportunities across the classroom day. They will also contribute to prepare teachers to be thoughtful and intentional in their interactions with young children.

\section{References}

Barros S., Aguiar C. (2010) Assessing the quality of Portuguese child care programs for toddlers, "Early Childhood Research Quarterly", 25: 527-535.

Booren L. M., Downer J. T., Vitiello V. E. (2013) Observations of children's interactions with teachers, peers, and tasks across preschool classroom activity settings, "Early Education and Development", 23 (4): 517-538.

Cadima J., Leal T., Burchinal M. (2010) The quality of teacher-student interactions: Associations with first graders' academic and behavioral outcomes, "Journal of School Psychology", 48: 457-482.

Cryer D., Tietze W., Burchinal M., Leal T., Palacios J. (1999) Predicting process quality from structural quality in preschool programs: A cross-country comparison, "Early Childhood Research Quarterly", 14: 339-361.

Early D. M., Iruka I. U., Ritchie S., Barbarin O. A., Winn D. C., Crawford G. M., Pianta R. C. (2010) How do pre-kindergarteners spend their time? Gender, ethnicity, and income as predictors of experiences in pre-kindergarten classrooms, "Early Childhood Research Quarterly", 25: 177-193.

European Commission/EACEA/Eurydice/Eurostat (2014) Key Data on Early Childhood Education and Care in Europe, Eurydice and Eurostat Report, Luxembourg: Publications Office of the European Union.

Fuligni A. S., Howes C., Huang Y., Hong S. S., Lara-Cinisomo S. (2012) Activity settings and daily routines in preschool classrooms: Diverse experiences in early learning settings for low-income children, "Early Childhood Research Quarterly", 27: 198-209.

Hamre B. K., Pianta R. C., Downer J. T., DeCoster J., Mashburn A. J., Jones S., Hamagami A. (2013) Teaching Through Interactions: Testing a developmental framework of teacher effectiveness in over 4,000 classrooms, "The Elementary School Journal", 113: 461-487.

Howes C., Guerra A. W., Fuligni A., Zucker E., Lee L., Obregon N. B., Spivak A. (2011) Classroom dimensions predict early peer interaction when children are diverse in ethnicity, race, and home language, "Early Childhood Research Quarterly", 26: 399-408.

La Paro K., Hamre B., Pianta R. (2012) Classroom assessment scoring system (CLASS) manual, toddler, Baltimore, MD, Paul H. Brookes. 
Lerkkanen M. K., Kiuru N., Pakarinen E., Viljaranta J., Poikkeus A. M., Rasku-Puttonen H., Siekkinen M., Nurmi J. E. (2012) The role of teaching practices in the development of children's interest in reading and math in kindergarten, "Contemporary Educational Psychology", 37 (4): 266-279.

Leseman P. P. M. (2013) Quality of the early years provisions: an European perspective (working paper). Utrecht, the Netherlands, Utrecht University, Department of Special Education.

Mashburn A. J., Pianta R. C., Hamre B. K., Downer J. T., Barbarin O. A., Bryant D., Howes C. (2008) Measures of classroom quality in prekindergarten and children's development of academic, language, and social skills, "Child Development", 79: 732-749.

Melhuish E. C. (2004) Child Benefits: The importance of investing in quality childcare, London, Daycare Trust.

Pessanha M., Aguiar C., Bairrao J. (2007) Influence of structural features on Portuguese toddler child care quality, "Early Childhood Research Quarterly", 22: 204-214.

Resa E., Ereky-Stevens K., Wieduwilt N., Penderi E., Anders Y., Petrogiannis K., Melhuish E. (2016) Overview of quality monitoring systems and results of moderator analysis. CARE Curriculum Quality Analysis and Impact Review of European ECEC, WP4, D4.3. Scientific report submitted to European Commission. Call Identifier: FP7-SSH2013-2, Brussels, European Commission.

Shonkoff J., Phillips D. (eds.) (2000) From Neurons to Neighborhoods: The Science of Early Childhood Development, Washington, DC, National Academy Press.

\section{Electronic sources}

Cabell S. Q., DeCoster J., LoCasale-Crouch J., Hamre B. K., Pianta R. C. (2013) Variation in the effectiveness of instructional interactions across preschool classroom settings and learning activities, "Early Childhood Research Quarterly", 28(4): 820-830, doi:10.1016/j.ecresq.2013.07.007.

Cadima J., Verschueren K., Leal T., Guedes C. (2016) Classroom interactions, dyadic teacher-child relationships, and self-regulation in socially disadvantaged young children, "Journal of Abnormal Child Psychology", 44: 7-17, doi: 10.1007/s10802-0150060-5.

La Paro K. M., Williamson A. C. Hatfield B. (2014) Assessing quality in toddler classrooms using the CLASS-Toddler and the ITERS-R, "Early Education and Development", 25 (6): 875-893, doi: 10.1080/10409289.2014.883586. 
Organization for Economic Co-operation \& Development [OECD] (2006) OECD Starting Strong II early childhood education and care: Portugal, retrieved from http:// www.oecd.org/education/school/37423722.pdf

Phillips D. A., Fox N. A., Gunnar M. R. (2011) Same place, different experiences: Bringing individual differences to research in childcare, "Child Development Perspectives", 5: 44-49, doi:10.1111/j.1750-8606.

Slot P., Cadima J., Salminen J., Pastori G., Lerkkanen M.-K. (2016) Multiple case study in seven European countries regarding culture-sensitive classroom quality assessment. CARE Curriculum Quality Analysis and Impact Review of European ECEC, WP2, D2.3, Executive summary, retrieved from http://ecec-care.org/fileadmin/careproject/ Publications/reports/summaries/D2_3_Multiple_Case_study_executive_summary.pdf 